\title{
Occurrence of ss/ genes in isolates of Staphylococcus aureus from animal infection
}

\section{Correspondence \\ Cyril J. Smyth \\ csmyth@tcd.ie}

Received 6 August 2006

Accepted 26 October 2006

\author{
Davida S. Smyth, ${ }^{1} \dagger$ William J. Meaney, ${ }^{2}$ Patrick J. Hartigan ${ }^{3}$ \\ and Cyril J. Smyth ${ }^{1}$ of Dublin, Dublin 2, Ireland
${ }^{2}$ Teagasc, Dairy Production Research Centre, Moorepark, Fermoy, Co. Cork, Ireland
${ }^{3}$ Department of Physiology, School of Medicine, Trinity College, University of Dublin, Dublin 2, Ireland \\ ${ }^{1}$ Department of Microbiology, Moyne Institute of Preventive Medicine, Trinity College, University
}

\begin{abstract}
The occurrence of 7 of the 11 known ss/ genes that are found within the $v$ Sa $\alpha$ genomic island of Staphylococcus aureus and encode the novel Ssl family of exoproteins was examined in isolates from cows (42 isolates), goats (4 isolates), sheep ( 1 isolate), rabbits ( 3 isolates) and chickens (2 isolates). Based on seven $S$. aureus genome sequences for human strains NCTC 8325 , N315, Mu50, COL, MRSA 252, MW2 and MSSA-476, and bovine strain RF122, along with the ss/ reference gene sequences from strains NCTC 6571, FRI326 and NCTC 8325, ClustalWgenerated alignments were used to design PCR primers for unique regions of the ss/ genes that are present in the allelic variants of each, except for the ss/4 gene for which specific primers for the set2 and set9 allelic variants were designed individually. The genotypes of isolates were determined using random amplified polymorphic DNA (RAPD) typing. All of the animal-associated $S$. aureus isolates contained an ss/locus, but there were minor variations in the number of ss/genes present. Forty-nine of the animal isolates possessed a $v \mathrm{Sa} \alpha$ genomic island containing the $s s / 3$ (set8), ss/5 (set3/set10), ss/7 (set1/set11), ss/8 (set12), ss/9 (set5/set13) and ss/10 (set4/set14) genes. One bovine and one goat isolate lacked the ss/3 gene. The $s s / 9$ gene was absent in one bovine isolate. The goat isolate lacking the $s s / 3$ gene was the only animal isolate that possessed the set2 allele of the ss/4 gene. PCR for the set 9 allele of the ss/4 gene was inconclusive. Isolates that showed identical RAPD fingerprints had the same complement of ss/ genes, but the ss/ gene pattern was not RAPD-type specific. Southern blot hybridization showed similar ss/ gene RFLPs in isolates of the same RAPD type.
\end{abstract}

\section{INTRODUCTION}

Staphylococcus aureus causes a wide variety of clinical syndromes ranging from uncomplicated infections of the skin, such as boils and carbuncles, to life-threatening infections, such as endocarditis and toxic shock syndrome (Murray, 2005; Todd, 2005). S. aureus is also an important pathogen of animals including cows, goats, sheep, rabbits and chickens (Rich, 2005; Barkema et al., 2006). Among the many known virulence factors of $S$. aureus are three groups of staphylococcal exoproteins: the enzymes such as hyaluronidase, proteases and nucleases; the non-enzymic activators of plasma clotting (coagulase) and fibrinolysis (staphylokinase); and the exotoxins, namely, cytolytic toxins, exfoliative toxins, leukocidins, enterotoxins, enterotoxin-like proteins

tPresent address: New York Medical College, Department of Microbiology and Immunology, Valhalla, NY 10595, USA.

Abbreviation: RAPD, random amplified polymorphic DNA. and toxic shock syndrome toxin no. 1 (TSST-1) (Ferry et al., 2005). The enterotoxins, enterotoxin-like proteins and TSST-1 belong to the superantigen (SAg) family (Proft \& Fraser, 2003). Nineteen staphylococcal enterotoxins (SEs) and staphylococcal enterotoxin-like (SEl) proteins, as well as a number of variants of some of these, have been described (Smyth et al., 2004; Thomas et al., 2006).

In addition to these superantigens, S. aureus also produces a family of exoproteins termed the staphylococcal exotoxinlike (Set) proteins (Williams et al., 2000), which have since been renamed staphylococcal superantigen-like (Ssl) proteins (Lina et al., 2004). The Ssl proteins are encoded by a cluster of genes (also termed genomic island $v S a \alpha$; Lindsay \& Holden, 2004, 2006) that show sequence similarity of 36-67\% (Williams et al., 2000; Kuroda et al., 2001). The $v \mathrm{Sa} \alpha$ island is flanked upstream by a putative transposase gene, and downstream by an incomplete restriction and modification system (the $h s d S$ and $h s d M$ genes) forming 
part of a three-component restriction/modification system (HsdS, HsdM and HsdR) that is believed to maintain the locus in the genome (Kuroda et al., 2001). Although the crystal structures of the Ssl5 and Ssl7 proteins revealed that these had overall folding characteristics and the classical two-domain structure of the SAg family, the major histocompatibility complex-binding site of superantigens had been lost, accounting for the inability of Ssl proteins to induce T-cell proliferation (Arcus et al., 2002; Al-Shangiti et al., 2004)

Microarray analysis using 63 isolates from humans, sheep, cows and poultry (Fitzgerald et al., 2003) showed that the ssl locus was present in all of the $S$. aureus isolates tested, but varied in size from 12 to $17 \mathrm{~kb}$ and displayed high levels of sequence variation. It was theorized that horizontal gene transfer, recombination events, and loss of ssl genes had led to this diversity. Recently Tsuru et al. (2006) compared whole genomic sequences of human strains of $S$. aureus and identified conserved sequences (45 and $61 \mathrm{bp}$ repeats flanking indels) between the ssl genes and at identical relative positions, which could be functionally important in generating deletions by homologous recombination in the variable region between the $s s l 3$ and $s s l 9$ genes.

At the start of this work very limited data were available on the occurrence of individual ssl genes in $S$. aureus isolates from animals (Fitzgerald et al., 2003). The aims of this study were to develop a PCR-based screening method for ssl genes within the variable region of the $v \mathrm{Sa} \alpha$ genomic island and to investigate the occurrence of these genes in isolates of S. aureus of animal origin.

\section{METHODS}

Strains. Fifty-two isolates associated with animal $S$. aureus infections, namely, broiler chicken osteomyelitis $(n=2)$, rabbit staphylococcosis $(n=3)$ and mastitis (cows $=42$, sheep $=1$, goats $=4)$, which included animal-associated clonal types previously identified by molecular fingerprinting techniques (Rodgers et al., 1999; Fitzgerald et al., 1997, 2000; Hermans et al., 2000; Foschino et al., 2002), were examined. These were confirmed to belong to animal-associated clonal types using multiple locus sequence typing (Smyth, 2006). Six human control strains, MRSA 252, NCTC 8325-4, MSSA-476, COL and NCTC 6571, and one clinical human isolate (strain MSA 2335), were also used. S. aureus isolates were routinely grown on either trypticase soy agar (TSA) (Oxoid) or trypticase soy broth (Oxoid) with shaking at $37^{\circ} \mathrm{C}$. The identification of $S$. aureus isolates was verified by testing their ability to grow and produce acid on mannitol salt agar, a positive coagulase test, their ability to produce acetoin, their ability to grow on TSA supplemented with $7 \mu$ g acriflavin $\mathrm{ml}^{-1}$ (Devriese, 1981), and a negative PCR for the Staphylococcus intermedius $16 \mathrm{~S}$ rRNA gene.

Analysis of the S. aureus genome sequences using Artemis and BLASTN and translated amino acid sequences using BLASTX. Seven available $S$. aureus genome sequences for strains NCTC 8325, N315, Mu50, COL, MRSA 252, MW2 and MSSA-476, the $s s l$ reference gene sequences from strains NCTC 6571, FRI326 and NCTC 8325, and the ssl locus sequences of bovine strain RF122 and of three human-associated strains JH1, JH9 and USA300 (Table 1) were downloaded and analysed by Artemis, a freeware sequence analysis tool available at the Sanger Centre website (www.sanger.ac.uk) and BLASTN (http://www.ncbi.nlm.nih.gov/blast/) to determine the composition of the $s s l$ locus in each strain. Once a putative identity had been assigned to each ORF of each genome sequence, the ORFs from each genome were aligned with each other using ClustalW (www.ebi.ac.uk/clustalW) and ClustalX (ftp://ftpigbmc.u-strasbg.fr/pub/ClustalX/).

From the analysis it was observed that the ssl genes of each sequenced $S$. aureus strain varied in number and composition, and that there were a number of allelic variants of certain ssl genes, namely, ssl3 (set8), ssl5 (set3/set10), ssl7 (set1/set11), ssl8 (set12), ssl9 (set5/set13) and ssl10 (set4/ set14). A schematic of the ssl loci from 11 human-associated S. aureus strains and the bovine strain RF122 is shown in Fig. 1. Using BLASTX it was possible to compare the translated amino-acid sequences of the $s s l$ genes from the genome sequence of strain N315 with the amino-acid sequences of the ssl proteins of NCTC 6571, the archetypal set gene cluster strain, already in the NCBI protein database (Williams et al., 2000). The output of BLASTX showed that the ssl genes from strains N315 and NCTC 6571 have translated amino-acid sequence similarities ranging from 29 to $66 \%$ between individual pairs of genes, whereas the tandem paralogues within these strains have higher degrees of similarity (76-89\%). The translated amino-acid similarities of the $s s l 3$ and $s s l 4$ genes in strains N315 and NCTC 6571 were high, with the set 2 allelic variant of the ssl3 gene (present in strain NCTC 6571) showing $87 \%$ and $76 \%$ translated amino-acid similarity to the set 8 and set 9 allelic variants of the ssl4 gene (present in strain N315), respectively.

DNA isolation. Extraction of genomic DNA from S. aureus was performed as previously described with minor modifications (Fitzgerald et al., 1997). The procedure involves lysostaphin lysis, proteinase $\mathrm{K}$ treatment, addition of EDTA, sarkosyl and cetyltrimethylammonium bromide (CTAB), extraction with chloroform/ isoamyl alcohol and phenol/chloroform/isoamyl alcohol, and precipitation with ethanol.

Design of primers and PCR analysis. Using ClustalW/ClustalXgenerated alignments it was possible to locate unique regions of each $s s l$ gene that were present in their respective set allelic variants, except for the ssl4 gene. These unique regions were used to design PCR primers for the $s s l$ alleles, and to amplify PCR products for use as probes in Southern blot hybridization experiments (Table 2). Each set of primers used the same PCR mix comprising $10 \mathrm{pmol}$ forward and reverse primers, $200 \mu \mathrm{M}$ each of dATP, dTTP, dCTP and dGTP, $1 \times$ magnesium-free buffer (Promega), $1.5 \mathrm{U}$ Taq DNA polymerase (Promega), $3 \mathrm{mM} \mathrm{MgCl}$, and 50-100 ng DNA. PCR tests also included appropriate ssl gene-positive and -negative controls (DNA from reference human strains NCTC 8325-4, MRSA 252, MSSA-476, COL and NCTC 6571).

The PCRs used the following cycling parameters: $95^{\circ} \mathrm{C}$ for $10 \mathrm{~min}, 15$ cycles of $\left(95^{\circ} \mathrm{C}\right.$ for $1 \mathrm{~min}, 58^{\circ} \mathrm{C}$ for $45 \mathrm{~s}$ and $72^{\circ} \mathrm{C}$ for $\left.1 \mathrm{~min}\right)$ and 16 cycles of $\left(95^{\circ} \mathrm{C}\right.$ for $1 \mathrm{~min}, 54^{\circ} \mathrm{C}$ for $45 \mathrm{~s}$ and $72^{\circ} \mathrm{C}$ for $\left.1 \mathrm{~min}\right)$. The reaction was terminated with a $10 \mathrm{~min}$ incubation at $72^{\circ} \mathrm{C}$. PCR products were resolved by electrophoresis in $1.5 \%(\mathrm{w} / \mathrm{v})$ agarose gel $(0.5 \times$ Tris/boric acid/EDTA buffer) (Sambrook \& Russell, 2001) at $90 \mathrm{~V}$ (constant voltage), stained with ethidium bromide, and visualized using UV light. Product sizes were determined by comparison with a $100 \mathrm{bp}$ ladder (Promega).

Southern blotting and ssl gene RFLP analysis. The presence of the ssl locus within isolates that were positive by PCR was confirmed using Southern blotting of genomic DNA from a number of representative Irish and American bovine isolates from the study of Fitzgerald et al. (1997) and human-associated control strains. Genomic DNA was digested with restriction endonuclease HindIII, which cuts within the $h s d M$, hsdS genes of control strain MRSA 252. The resulting fragments were resolved by electrophoresis in $0.8 \%$ agarose. Southern blot 
Table 1. S. aureus genomic sequences and ss/ reference gene sequences examined using Artemis and BLASTN/BLASTX

\begin{tabular}{|c|c|c|c|}
\hline Strain & Origin (year of isolation)* & $\begin{array}{c}\text { GenBank } \\
\text { accession no. }\end{array}$ & Reference \\
\hline Mu50 & $\begin{array}{l}\text { Pus from surgical wound, VRSA, Juntendo University } \\
\text { Hospital, Tokyo, Japan (1997) }\end{array}$ & NC_002758 & Kuroda et al. (2001) \\
\hline N315 & $\begin{array}{l}\text { Pharyngeal smear, MRSA, Nagasaki University Hospital, } \\
\text { Japan (1982) }\end{array}$ & NC_002745 & Kuroda et al. (2001) \\
\hline RF122 & Bovine mastitis, Ballymacoda, Ireland (1993) & NC_007622 & $\begin{array}{l}\text { Fitzgerald et al. (2001); } \\
\text { Herron-Olson and others, } \\
\text { GenBank database } 2005\end{array}$ \\
\hline NCTC 8325 & Corneal ulcer, Oxford, UK (1943) & $\begin{array}{l}\text { NC_007795, } \\
\text { AF188837 }\end{array}$ & $\begin{array}{l}\text { Richardson et al. (1994); } \\
\text { Gillaspy et al. (2006) }\end{array}$ \\
\hline COL & Operating theatre, London, UK (approximately 1960) & NC_002951 & Gill et al. (2005) \\
\hline MRSA 252 & Postoperative infection, EMRSA-16 clone (1997) & NC_002923 & Holden et al. (2004) \\
\hline MW2 & $\begin{array}{l}\text { Fatal septicaemia and septic arthritis, CA-MRSA, North } \\
\text { Dakota, USA (1998) }\end{array}$ & NC_003923 & Baba et al. (2002) \\
\hline MSSA-476 & Tibial osteomyelitis and bacteraemia, invasive (1998) & NC_002953 & Holden et al. (2004) \\
\hline \multirow[t]{2}{*}{ NCTC 6571} & Pleural fluid (1935) & AF094826 & Williams et al. (2000) \\
\hline & & AF188835 & Williams et al. (2000) \\
\hline FRI326 & $\begin{array}{l}\text { Chicken tetrazzini, food poisoning, enterotoxin E, Chicago, } \\
\text { USA (1960) }\end{array}$ & AF188836 & Williams et al. (2000) \\
\hline JH1 & Blood culture, MRSA, Baltimore, USA (2001) & NZ_AAPK00000000 & $\begin{array}{l}\text { Copeland and others, GenBank } \\
\text { database } 2006\end{array}$ \\
\hline JH9 & Blood culture, VISA, Baltimore, USA (2001) & NZ_AAPL00000000 & $\begin{array}{l}\text { Copeland and others, GenBank } \\
\text { database } 2006\end{array}$ \\
\hline USA300 (FPR3757) & Wrist abscess, CA-MRSA, San Francisco, USA (2002) & NC_007793 & Diep et al. (2006) \\
\hline
\end{tabular}

${ }^{\star}$ CA-MRSA, community-acquired, meticillin-resistant S. aureus; EMRSA-16, epidemic meticillin-resistant S. aureus type 16; MRSA, meticillinresistant S. aureus; VISA, vancomycin intermediate-resistant $S$. aureus; VRSA, vancomycin-resistant S. aureus.

hybridization analysis was performed using standard methods (Sambrook \& Russell, 2001) and the DIG-labelling system (Roche). Probes were constructed using the PCR DIG-labelling mix (Roche) in PCRs that incorporated DIG-labelled dUTP into the synthesized DNA. Probes were designed to target genes that were present in all isolates tested and therefore would allow a comparison of RFLPs across all isolates analysed. Probes for the $s s l 7$ and ssl5 genes were amplified using genomic DNA from human strain NCTC 6571, and a probe for the ssl8 gene using genomic DNA from bovine strain RF122.

Random amplified polymorphic DNA (RAPD) typing. RAPD typing was carried out as previously described (Fitzgerald et al., 1997; Smyth et al., 2006). Briefly it was performed in a final volume of $25 \mu \mathrm{l}$ consisting of $1 \mu \mathrm{l}$ chromosomal DNA (approx. $100 \mathrm{ng}$ ), $2 \mu \mathrm{l}$ 23-mer primer D11344 (20 pmol $\mu^{-1}$ ) (Akopyanz et al., 1992), $2.5 \mathrm{U}$ Taq DNA polymerase (Promega), $2.5 \mu \mathrm{l} 10 \times$ buffer (Promega), $3 \mu \mathrm{l} 25 \mathrm{mM} \mathrm{MgCl} 2$ buffer (Promega), and $0.2 \mathrm{mM}$ dNTPs. The PCR program used was 4 cycles of $\left(94^{\circ} \mathrm{C}\right.$ for $5 \mathrm{~min}$, $40^{\circ} \mathrm{C}$ for $5 \mathrm{~min}, 72^{\circ} \mathrm{C}$ for $\left.5 \mathrm{~min}\right)$ and then 30 cycles of $\left(94^{\circ} \mathrm{C}\right.$ for $1 \mathrm{~min}, 55^{\circ} \mathrm{C}$ for $1 \mathrm{~min}, 72^{\circ} \mathrm{C}$ for $2 \mathrm{~min}$ ). Of the PCR products $5 \mu \mathrm{l}$ was run on a $2 \%(\mathrm{w} / \mathrm{v})$ agarose gel. Strains that generated the same banding pattern were considered to be of the same RAPD type.

\section{RESULTS}

\section{PCR for ssl genes}

PCR was done on strains NCTC 8325-4, MSSA-476, MRSA 252, COL and NCTC 6571, each of known genome sequence and ssl gene content, and on a clinical isolate (MSA 2335). The ssl genes tested for were all amplifiable by PCR and the results for these strains were consistent with their ssl genomic island sequences (Table 3, Fig. 1). PCR analysis of the animal-associated $S$. aureus isolates showed that, whereas all of them contained an $s s l$ locus, there were minor variations in the number of ssl genes encoded (Table 3). The ssl5, ssl7, ssl8 and ssl10 genes were present in all of the animal-associated isolates. The $s s l 9$ gene was present in all isolates bar one bovine isolate, namely, isolate MSA1455. The $s s l 3$ gene was present in 50 of the 52 animal-associated isolates tested, except for one bovine (MSA1003) and one caprine isolate (St24).

The set 2 allelic variant of the ssl 4 gene was found to be present in 1 of the 52 animal-associated isolates (St24 from a goat). In contrast to PCR findings with strains NCTC 8325, MSSA-479 and COL PCR, for each of which the set 9 allelic variant of the $s s l 4$ gene was amplifiable using the designed primers (Fig. 1, Table 2), PCR for the ssl4 (set9) allele with the animal isolates was inconclusive. The primers for the set 9 allelic variant of the ssl 4 gene generated multiple nonspecific products with the animal isolates, including strain RF122, which is known to lack the ssl4 gene based on the genomic sequence data (Fig. 1). This implies that the primers could anneal to other targets, possibly ssl-like 


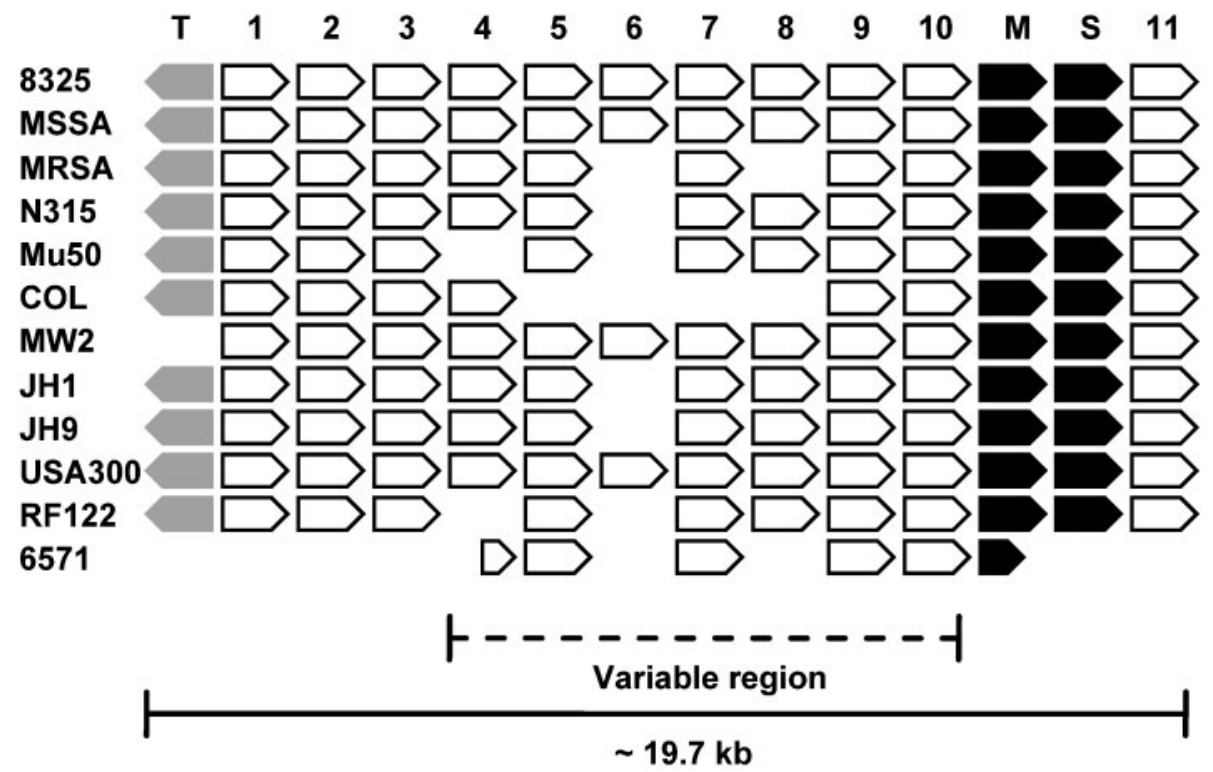

Fig. 1. Schematic of the ss/ locus based on $S$. aureus genome and ss/ locus sequences. The staphylococcal genomes show variation in the number and complement of $s s /$ alleles. There is a central variable region that contains allelic variants of $s s /$ genes, e.g. the ss/5 gene (formerly set3 and set10) and the ss/7 gene (formerly set1 and set11) have variants. Deletions of ss/ genes also occur, e.g. the ss/6 gene is only present in strains NCTC 8325, MSSA-476, USA300 and MW2. Strain RF122 is a bovine strain, while the rest are of human origin. The ss/ genes are numbered above the diagram. T, putative transposase gene; $\mathrm{M}$, hsdM gene; $S$, hsdS gene of the restriction and modification system; 8325, NCTC 8325; 6571, NCTC 6571; MSSA, MSSA-476; MRSA, MRSA 252.

sequences, in the animal isolates. While 5 other isolates (RF102, RF108, RF110, FR120 and RF121) included in this study are of the same RAPD type 33 as strain RF122 (see below and Table 3), and thus might be surmised to lack the ssl4 gene, it seems highly likely that a number of the other 45 animal isolates might test positive for the set 9 allelic variant

Table 2. Primers used in ssl (set) gene PCR

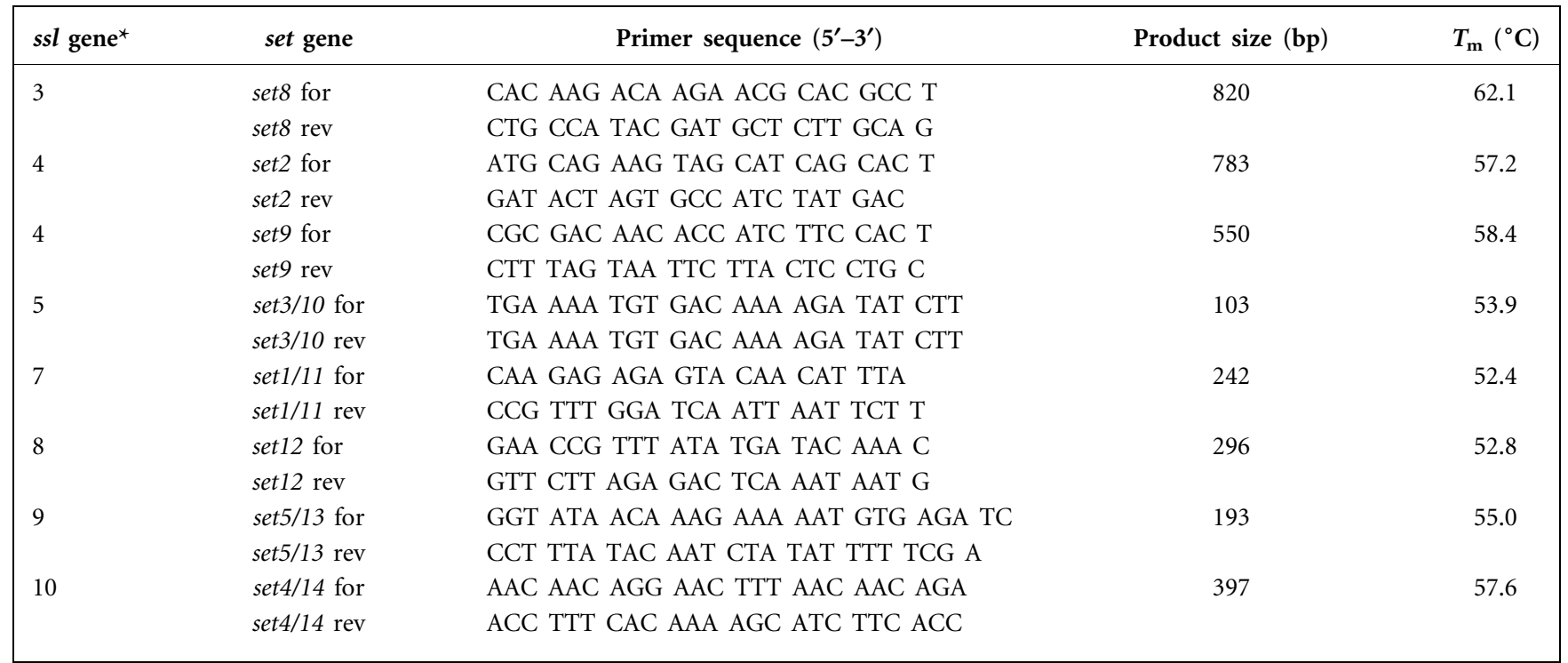

${ }^{*}$ Not all $s s l$ genes were tested for $(s s l 1, s s l 2, s s l 6$ and $s s l 11$ were omitted). It was not possible to design a primer to amplify both the $s e t 9$ and $s e t 2$ allelic variants of $s s l 4$ so individual primers were used. Primers would amplify all allelic variants of $s s l$ genes, e.g. the $s s l 10$ primers would amplify both the set4 allele of strain MRSA252 and the set 14 allele of strain NCTC 8325. 
Table 3. Combinations of ss/ genes in 52 isolates of $S$. aureus of animal origin and 6 control human strains

\begin{tabular}{|c|c|c|c|c|c|c|c|c|c|c|c|c|}
\hline \multirow[t]{2}{*}{ Strain/isolate ${ }^{\star}$} & \multirow[t]{2}{*}{ Origin } & \multirow[t]{2}{*}{ Host } & \multicolumn{2}{|c|}{ Known characteristic } & \multirow{2}{*}{$\begin{array}{l}\text { RAPD } \\
\text { type } \$\end{array}$} & \multicolumn{7}{|c|}{ ssl genell } \\
\hline & & & $\begin{array}{l}\text { SAg and SAg- } \\
\text { like genes } \dagger\end{array}$ & Mitogenicity $\ddagger$ & & & & & & & & \\
\hline NCTC $8325-4$ & USA & Human & None & ND & ND & 3 & 4 & 5 & 7 & 8 & 9 & 10 \\
\hline MSSA-476 & UK & Human & sea, seh & ND & ND & 3 & 4 & 5 & 7 & 8 & 9 & 10 \\
\hline MRSA 252 & UK & Human & $e g c$ & ND & ND & 3 & 4 & 5 & 7 & & 9 & 10 \\
\hline NCTC 6571 & USA & Human & $e g c$ & ND & ND & 3 & 4 & 5 & 7 & & 9 & 10 \\
\hline MSA 2335 & USA & Human & ND & ND & ND & & 4 & 5 & 7 & 8 & 9 & 10 \\
\hline RF101 & IRL & Cow & Negative & - & 11 & 3 & & 5 & 7 & 8 & 9 & 10 \\
\hline RF102 & IRL & Cow & SaPIbov, $e g c$ & + & 33 & 3 & & 5 & 7 & 8 & 9 & 10 \\
\hline RF103 & IRL & Cow & Negative & + & 11 & 3 & & 5 & 7 & 8 & 9 & 10 \\
\hline RF107 & IRL & Cow & Negative & - & 11 & 3 & & 5 & 7 & 8 & 9 & 10 \\
\hline RF115 & IRL & Cow & Negative & - & 16 & 3 & & 5 & 7 & 8 & 9 & 10 \\
\hline RF116 & IRL & Cow & Negative & - & 16 & 3 & & 5 & 7 & 8 & 9 & 10 \\
\hline RF117 & IRL & Cow & Negative & - & 16 & 3 & & 5 & 7 & 8 & 9 & 10 \\
\hline RF120 & IRL & Cow & $e g c$ & + & 33 & 3 & & 5 & 7 & 8 & 9 & 10 \\
\hline RF121 & IRL & Cow & $e g c$ & + & 33 & 3 & & 5 & 7 & 8 & 9 & 10 \\
\hline RF122 & IRL & Cow & SaPIbov, egc & + & 33 & 3 & & 5 & 7 & 8 & 9 & 10 \\
\hline RF123 & IRL & Cow & Negative & - & 11 & 3 & & 5 & 7 & 8 & 9 & 10 \\
\hline RF285 & IRL & Cow & SaPIbov & + & 23 & 3 & & 5 & 7 & 8 & 9 & 10 \\
\hline RF286 & IRL & Cow & SaPIbov & + & 23 & 3 & & 5 & 7 & 8 & 9 & 10 \\
\hline $2(2521-3 r d)$ & IRL & Cow & seh & ND & ND & 3 & & 5 & 7 & 8 & 9 & 10 \\
\hline $6(2242-3 r d)$ & IRL & Cow & seh & ND & ND & 3 & & 5 & 7 & 8 & 9 & 10 \\
\hline MSA13.1 & USA & Cow & ND & ND & 31 & 3 & & 5 & 7 & 8 & 9 & 10 \\
\hline MSA17.1 & USA & Cow & $e g c$ & \pm & 35 & 3 & & 5 & 7 & 8 & 9 & 10 \\
\hline MSA103.14 & USA & Cow & $e g c$ & + & ND & 3 & & 5 & 7 & 8 & 9 & 10 \\
\hline MSA148 & USA & Cow & $e g c$ without $s e g$ & + & ND & 3 & & 5 & 7 & 8 & 9 & 10 \\
\hline MSA915 & USA & Cow & $e g c$ & ND & 16 & 3 & & 5 & 7 & 8 & 9 & 10 \\
\hline MSA916 & USA & Cow & Negative & - & 24 & 3 & & 5 & 7 & 8 & 9 & 10 \\
\hline MSA927 & USA & Cow & Negative & - & ND & 3 & & 5 & 7 & 8 & 9 & 10 \\
\hline MSA930 & USA & Cow & egc without $s e g$ & + & ND & 3 & & 5 & 7 & 8 & 9 & 10 \\
\hline MSA948 & USA & Cow & Negative & ND & 19 & 3 & & 5 & 7 & 8 & 9 & 10 \\
\hline MSA1003 & USA & Cow & Negative & - & 16 & & & 5 & 7 & 8 & 9 & 10 \\
\hline MSA1006 & USA & Cow & sed, selj & ND & 3 & 3 & & 5 & 7 & 8 & 9 & 10 \\
\hline MSA1058 & USA & Cow & Negative & - & ND & 3 & & 5 & 7 & 8 & 9 & 10 \\
\hline MSA1363 & USA & Cow & $e g c$ & + & 6 & 3 & & 5 & 7 & 8 & 9 & 10 \\
\hline MSA1369 & USA & Cow & ND & ND & 11 & 3 & & 5 & 7 & 8 & 9 & 10 \\
\hline MSA1455 & USA & Cow & Negative & - & ND & 3 & & 5 & 7 & 8 & & 10 \\
\hline MSA1460 & USA & Cow & $e g c$ & + & ND & 3 & & 5 & 7 & 8 & 9 & 10 \\
\hline MSA1468 & USA & Cow & Negative & \pm & 21 & 3 & & 5 & 7 & 8 & 9 & 10 \\
\hline St65 & ITA & Goat & Negative & ND & 42 & 3 & & 5 & 7 & 8 & 9 & 10 \\
\hline St66 & ITA & Goat & Negative & ND & 42 & 3 & & 5 & 7 & 8 & 9 & 10 \\
\hline St24 & ITA & Goat & $s e c$, tst & ND & 7 & & 4 & 5 & 7 & 8 & 9 & 10 \\
\hline
\end{tabular}


Table 3. cont.

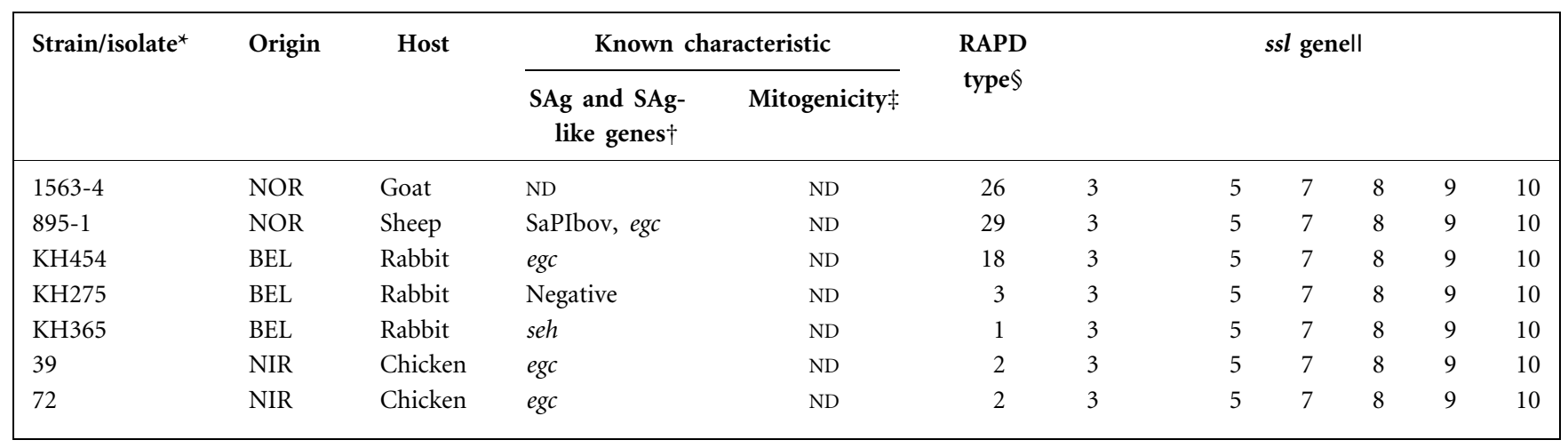

$\mathrm{ND}$, Not done.

*Strains 2, 6, 7, 10,12,14, 21 and 22 were isolated from milk samples from cows with recent mastitis and were not included in Smyth et al. (2005); the numbers in parentheses refer to the cow and the udder quarter from which the milk sample was obtained.

$\dagger$ sea ( $s e b, s e c$, sed, seg, seh), staphylococcal enterotoxin a (b, c, d, g, h); selj (selk, selq), staphylococcal enterotoxin-like $\mathrm{j}$ ( $\mathrm{k}$, q); egc, enterotoxin gene cluster comprising the seg, sei, selm, seln, selo genes, with either the selu gene or two pseudogenes $\psi$ ent 1 and $\psi$ ent 2 located between the sei and seln genes; SaPIbov, S. aureus pathogenicity island bovine possessing the sec-bovine, sell and tst genes (Fitzgerald et al., 2001; Jarraud et al., 2001; Letertre et al., 2003).

$\$$ Mitogenicity assay (ability to induce proliferation of human T-lymphocytes) results for 29 strains (Smyth et al., 2005) are indicated. +, positive, - , negative, \pm , borderline mitogenicity.

\$Although a number of the bovine strains included herein had been previously RAPD typed by Fitzgerald et al. (1997, 2000), for the purposes of the present study all RAPD typing was redone. RAPD types were numbered to provide a simple designation of RAPD genotype for in-house isolate comparison. Bovine RAPD types 4, 5 and 7 of Fitzgerald et al. (1997) are equivalent to our RAPD types 16, 11 and 33, respectively. IINot all of the genes encoded by the $s s l$ locus were investigated; only the seven genes that lie in the variable region of the $s s l$ locus were tested for.

of the ssl4 gene with redesigned primers as it occupies the same position as the set 2 variant. The PCR assay has as yet to be extended to screen animal isolates for the ssl6 gene (Fig. 1, strains NCTC 8325, MSSA-476 and MW2).

\section{RAPD typing}

A total of 26 of the 42 bovine isolates (16 Irish and 10 American) together with the 10 isolates from rabbits, sheep, goats and chickens were RAPD typed. Although isolates that showed identical RAPD fingerprints had the same complement of ssl genes (Table 3), the ssl gene pattern was not RAPD-type specific due to the high commonality in the $s s l$ locus in the tested animal isolates.

\section{Southern blot hybridization for ssl genes}

The $s s l 5, s s l 7$ and $s s l 8$ probes appeared to be specific for their target ssl genes. Southern blot hybridization experiments were performed on representative bovine isolates - isolates RF103 and MSA1369 (RAPD type 11), isolates RF115, RF116 and RF117 (RAPD type 16), isolates RF108 and RF122 (RAPD type 33) and isolates MSA1058 and MSA1369 (RAPD type not determined) - and human isolates MSSA476, MRSA 252, COL and NCTC 6571. The clonally related isolates by RAPD typing showed similar ssl gene RFLPs, whereas unrelated strains had dissimilar RFLPs (data not shown).

\section{DISCUSSION}

In the current study, the $s s l$ locus was found to be present in every animal-associated isolate, but showed minor variations in gene content by PCR and polymorphisms in RFLP patterns in Southern blots. The ssl locus had been reported in 49 S. aureus isolates from humans, 8 isolates from cows, 2 isolates from sheep, 2 isolates from poultry and 2 isolates of unknown species origin (Fitzgerald et al., 2003). However, no group had looked for the individual ssl genes with the exception of the set 1 allelic variant of the archetypal gene $s s l 7$ (Williams et al., 2000). The combination of ssl genes and their RFLP patterns in isolates of animal origin seem to reflect clonal relationships as revealed by RAPD typing, supporting the view that the locus is stable in the genome.

Twenty-nine of the isolates tested herein for ssl genes had been previously analysed for mitogenicity (Smyth et al., 2005). Of these 12 were non-mitogenic and negative for 16 SAg and SAg-like genes, and 14 were mitogenic and encoded SAg and SAg-like genes (Table 3). One isolate (RF103) was mitogenic and negative for SAg and SAg-like genes (the selp, selr, selu, selu2 and selv genes had not been tested for). The remaining two isolates exhibited borderline mitogenicity, one of which (isolate MSA17.1) possessed SAg and SAg-like genes, whereas the other (isolate MSA1468) did not. SAg and SAg-like gene-negative isolates (Table 3) that were shown to encode the ssl locus were non-mitogenic. The ability to stimulate $\mathrm{T}$-cells in a $\mathrm{V} \beta$-restricted manner is a 
hallmark of SAg activity. While species-restricted effects cannot be ruled out given that the animal isolates were tested on human T-lymphocytes, Ssl proteins associated with isolates of animal origin would appear not to be mitogenic, and thus not superantigenic, on the basis of this correlative analysis, which is in agreement with previous authors (Arcus et al., 2002; Fitzgerald et al., 2003; Al-Shangiti et al., 2004, 2005).

Langley et al. (2005) demonstrated that immobilized Ssl7 protein bound human IgA $\mathrm{H}$-chain and L-chain, and human complement component $\mathrm{C} 5 \alpha$ and $\mathrm{C} 5 \beta$ chains. Allelic variants of the Ssl7 protein were not altered in immunoglobulin- or complement-binding activities. These studies suggested that Ssl proteins are members of a much larger family of molecules with varied activities designed to bind serum components involved in host immunity. Thus, the Ssl proteins are likely involved in the interaction with $S$. aureus within various environments in different animal species. Allelic variation of the ssl gene cluster between animalassociated strains may confer an adaptive advantage to diverse conditions during infection of different animal tissues.

It has been demonstrated that strain COL expresses its $s s l$ genes concurrently and that multiple ssl genes are expressed during human infection, as evidenced by Western immunoblotting using sera from acute and convalescent patients (Arcus et al., 2002; Fitzgerald et al., 2003; Al-Shangiti et al., 2005). However, not all of the Ssl proteins are immunogenic. Expression of the ssl genes in vitro has yet to be shown for isolates from animal infection, and in vivo expression has not been demonstrated. Preliminary data using bovine sera from cows with and without mastitis has shown that the Ssl proteins, unlike proteins encoded by the egc (enterotoxin gene cluster) locus, are expressed in the host (Smyth, 2006). If multiple ssl genes are concurrently expressed during animal infection, the ssl genes may play an important role in staphylococcal pathogenicity, a suggestion given credence by the fact that every isolate tested herein had an $s s l$ locus. As has been described for staphylococcal enterotoxins, such as Sec-ovine and Sec-bovine, it is possible that animal-specific alleles of the ssl genes exist, the gene products of which might have particular functions in the infection of different animal hosts, e.g. recombinant Ssl7 protein from a bovineassociated strain might show higher affinity for bovine IgA. In vitro and in vivo expression studies of ssl genes of animal strains and affinity studies of Ssl proteins from animal-associated strains for IgA and complement factor C5 of the same animal origin are merited.

Aguiar-Alves et al. (2006) have newly described a genotyping method based on single nucleotide polymorphisms within sequenced PCR-amplified internal fragments of the set2, set5 and set7 genes (ssl4, ssl9 and ssl2 genes, respectively). This method was applied to clinical meticillinresistant and meticillin-susceptible $S$. aureus isolates allowing differentiation of 61 isolates into 22 distinct subgroups, designated exotoxin sequence types. As indicated herein,
RFLP patterns of selected ssl genes may have useful applications in epidemiology and typing, especially for laboratories without sequencing capabilities.

\section{ACKNOWLEDGEMENTS}

Warmest thanks to Robert Foschino, José R. Penadés, John D. Rodgers, Tore Tollersrud, Dieter Vancraeynest and Petra Winter who originally donated animal-associated strains used in this study, and to Keiichi Hiramatsu, Sean P. Nair, J. Ross Fitzgerald and John D. Fraser for providing helpful advice. Davida Smyth was supported by a Teagasc Walsh fellowship. This project was supported by a Teagasc research project grant number MKDC-0104-5067.

\section{REFERENCES}

Aguiar-Alves, F., Medeiros, F., Fernandes, O., Pereira, R. M. G., Perdreau-Remington, F. \& Riley, L. W. (2006). New Staphylococcus aureus genotyping method based on exotoxin (set) genes. J Clin Microbiol 44, 2728-2732.

Akopyanz, N., Bukanova, N. O., Westblom, T. U., Kresovich, S. \& Berg, D. E. (1992). DNA diversity among clinical isolates of Helicobacter pylori detected by PCR-based RAPD fingerprinting. Nucleic Acids Res 20, 5137-5142.

Al-Shangiti, A. M., Naylor, C. E., Nair, S. P., Briggs, D. C., Henderson, B. \& Chain, B. M. (2004). Structural relationships and cellular tropism of staphylocococcal superantigen-like proteins. Infect Immun 72, 4261-4270.

Al-Shangiti, A. M., Nair, S. P. \& Chain, B. M. (2005). The interaction between staphylococcal superantigen-like proteins and human dendritic cells. Clin Exp Immunol 140, 461-469.

Arcus, V. L., Langley, R., Proft, T., Fraser, J. D. \& Baker, E. N. (2002). The three-dimensional structure of a superantigen-like protein, SET3, from a pathogenicity island of the Staphylococcus aureus genome. J Biol Chem 277, 32274-32281.

Baba, T., Takeuchi, F., Kuroda, M., Yuzawa, H., Aoki, K.-i., Oguchi, A., Nagai, Y., Iwama, N., Asano, K. \& other authors (2002). Genome and virulence determinants of high virulence community-acquired MRSA. Lancet 359, 1819-1827.

Barkema, H. W., Schukken, Y. H. \& Zadoks, R. N. (2006). The role of cow, pathogen, and treatment regimen in the therapeutic success of bovine Staphylococcus aureus mastitis. J Dairy Sci 89, 1877-1895.

Devriese, L. A. (1981). Baird-Parker medium supplemented with acriflavine, polymyxins and sulphonamide for the selective isolation of Staphylococcus aureus from heavily contaminated materials. J Appl Bacteriol 50, 351-357.

Diep, B. A., Gill, S. R., Chang, R. F., Phan, T. H., Chen, J. H., Davidson, M. G., Lin, F., Lin, J., Carleton, H. A. \& other authors (2006). Complete genome sequence of USA300, an epidemic community-acquired methicillin-resistant Staphylococcus aureus. Lancet 367, 705-706.

Ferry, T., Perpoint, T., Vandenesch, F. \& Etienne, J. (2005). Virulence determinants in Staphylococcus aureus and their involvement in clinical syndromes. Curr Infect Dis Rep 7, 420-428.

Fitzgerald, J. R., Meaney, W. J., Hartigan, P. J., Smyth, C. J. \& Kapur, V. (1997). Fine-structure molecular epidemiological analysis of Staphylococcus aureus recovered from cows. Epidemiol Infect 119, 261-269.

Fitzgerald, J. R., Hartigan, P. J., Meaney, W. J. \& Smyth, C. J. (2000). Molecular population and virulence factor analysis of Staphylococcus 
aureus from bovine intramammary infection. J Appl Microbiol 88, 1028-1037.

Fitzgerald, J. R., Monday, S. R., Foster, T. J., Bohach, G. A., Hartigan, P. J., Meaney, W. J. \& Smyth, C. J. (2001). Characterization of a putative pathogenicity island from bovine Staphylococcus aureus encoding multiple superantigens. J Bacteriol 183, 63-70.

Fitzgerald, J. R., Reid, S. D., Ruotsalainen, E., Tripp, T. J., Liu, M. Y., Cole, R., Kuusela, P., Schlievert, P. M., Järvinen, A. \& Musser, J. M. (2003). Genome diversification in Staphylococcus aureus: molecular evolution of a highly variable chromosomal region encoding the staphylococcal exotoxin-like family of proteins. Infect Immun 71, 2827-2838.

Foschino, R., Invernizzi, A., Barucco, R. \& Stradiotto, K. (2002). Microbial composition, including the incidence of pathogens, of goat milk from the Bergamo region of Italy during a lactation year. J Dairy Res 69, 213-225.

Gill, S. R., Fouts, D. E., Archer, G. L., Mongodin, E. F., DeBoy, R. T., Ravel, J., Paulsen, I. T., Kolonay, J. F., Brinkac, L. \& other authors (2005). Insights on evolution of virulence and resistance from the complete genome analysis of an early methicillin-resistant Staphylococcus aureus strain and a biofilm-producing methicillin-resistant Staphylococcus epidermidis strain. J Bacteriol 187, 2426-2438.

Gillaspy, A. F., Worrell, V., Orvis, J., Roe, B. A., Dyer, D. W. \& landolo, J. J. (2006). The Staphylococcus aureus NCTC 8325 genome. In GramPositive Pathogens, pp. 381-412. Edited by V. A. Fischetti, R. P. Novick, J. J. Ferretti, D. A. Portnoy \& J. I. Rood. Washington, DC: American Society for Microbiology.

Hermans, K., Haesebrouck, F., Vaneechoutte, M., Devriese, L. A., Godard, C. \& De Herdt, P. (2000). Differentiation between high and low virulence Staphylococcus aureus strains from rabbits by randomly amplified polymorphic DNA (RAPD) analysis. Vet Microbiol 72, 311-319.

Holden, M. T. G., Feil, E. J., Lindsay, J. A., Peacock, S. J., Day, N. P. J., Enright, M. C., Foster, T. J., Moore, C. E., Hurst, L. \& other authors (2004). Complete genomes of two clinical Staphylococcus aureus strains: evidence for the rapid evolution of virulence and drug resistance. Proc Natl Acad Sci U S A 101, 9786-9791.

Jarraud, S., Peyrat, M. A., Lim, A., Tristan, A., Bes, M., Mougel, C., Etienne, J., Vandenesch, F., Bonneville, M. \& Lina, G. (2001). egc, a highly prevalent operon of enterotoxin gene, forms a putative nursery of superantigens in Staphylococcus aureus. J Immunol 166, 669-677.

Kuroda, M., Ohta, T., Uchiyama, I., Baba, T., Yuzawa, H., Kobayashi, I., Cui, L., Oguchi, A., Aoki, K.-i. \& other authors (2001). Whole genome sequencing of methicillin-resistant Staphylococcus aureus. Lancet 357, 1225-1240.

Langley, R., Wines, B., Willoughby, N., Basu, I., Proft, T. \& Fraser, J. D. (2005). The staphylococcal superantigen-like protein 7 binds IgA and complement C5 and inhibits IgA-Fc $\alpha$ RI binding and serum killing of bacteria. J Immunol 174, 2926-2933.

Letertre, C., Perelle, S., Dilasser, F. \& Fach, P. (2003). Identification of a new putative enterotoxin SEU encoded by the egc cluster of Staphylococcus aureus. J Appl Microbiol 95, 38-43.

Lina, G., Bohach, G. A., Nair, S. P., Hiramatsu, K., Jouvin-Marche, E. \& Mariuzza, R. (2004). Standard nomenclature for the superantigens expressed by Staphylococcus. J Infect Dis 189, 2334-2336.

Lindsay, J. A. \& Holden, M. T. G. (2004). Staphylococcus aureus: superbug, super genome? Trends Microbiol 12, 378-385.
Lindsay, J. A. \& Holden, M. T. G. (2006). Understanding the rise of the superbug: investigation of the evolution and genomic variation of Staphylococcus aureus. Funct Integr Genomics 6, 186-201.

Murray, R. J. (2005). Recognition and management of Staphylococcus aureus toxin-mediated disease. Intern Med J 35 (Suppl. 2), S106S109.

Proft, T. \& Fraser, J. D. (2003). Bacterial superantigens. Clin Exp Immunol 133, 299-306.

Rich, M. (2005). Staphylococci in animals: prevalence, identification and antimicrobial susceptibility, with an emphasis on methicillinresistant Staphylococcus aureus. Br J Biomed Sci 62, 98-105.

Richardson, J. F., Aparicio, P., Marples, R. R. \& Cookson, B. D. (1994). Ribotyping of Staphylococcus aureus: an assessment using well-defined strains. Epidemiol Infect 112, 93-101.

Rodgers, J. D., McCullagh, J. J., McNamee, P. T., Smyth, J. A. \& Ball, H. J. (1999). Comparison of Staphylococcus aureus recovered from personnel in a poultry hatchery and in broiler parent farms with those isolated from skeletal disease in broilers. Vet Microbiol 69, 189-198.

Sambrook, J. \& Russell, D. W. (2001). Molecular Cloning: a Laboratory Manual, 3rd edn. Cold Spring Harbor, NY: Cold Spring Harbor Laboratory.

Smyth, D. S. (2006). Molecular genetic typing of Staphylococcus aureus from cows, goats, sheep, rabbits and chickens. PhD thesis, University of Dublin.

Smyth, C. J., Smyth, D. S., Kennedy, J., Twohig, J. \& Bolton, D. (2004). Staphylococcus aureus: from man or animals - an enterotoxin iceberg? In Food Pathogen Epidemiology: Microbes, Maladies and Methods, Proceedings of European Union Risk Analysis Information Network (EURAIN) Conference, Padua, Italy, December 2004, pp. 85-102. Edited by B. Maunsell, J. Sheridan \& D. J. Bolton. Dublin: Teagasc - The National Food Centre.

Smyth, D. S., Hartigan, P. J., Meaney, W. J., Fitzgerald, J. R., Deobald, C. F., Bohach, G. A. \& Smyth, C. J. (2005). Superantigen genes encoded by the egc cluster and SaPIbov are predominant among Staphylococcus aureus isolates from cows, goats, sheep, rabbits and poultry. J Med Microbiol 54, 401-411.

Smyth, D. S., Kennedy, J., Twohig, J., Miajlović, H., Bolton, D. \& Smyth, C. J. (2006). Staphylococcus aureus isolates from Irish domestic refrigerators possess novel superantigen genes and are clonal in nature. J Food Prot 69, 508-515.

Thomas, D. Y., Jarraud, S., Lemercier, B., Cozon, G., Echasserieau, K., Etienne, J., Gougeon, M.-L. \& Vandenesch, F. (2006). Staphylococcal enterotoxin-like toxins $\mathrm{U} 2$ and $\mathrm{V}$, two new staphylococcal superantigens arising from recombination within the enterotoxin cluster. Infect Immun 74, 4724-4734.

Todd, J. K. (2005). Staphylococcal infections. Pediatr Rev 26, 444-450.

Tsuru, T., Kawai, M., Mizutani-Ui, Y., Uchiyama, I. \& Kobayashi, I. (2006). Evolution of paralogous genes: reconstruction of genome rearrangements through comparison of multiple genomes within Staphylococcus aureus. Mol Biol Evol 23, 1269-1285.

Williams, R. J., Ward, J. M., Henderson, B., Poole, S., O'Hara, B. P., Wilson, M. \& Nair, S. P. (2000). Identification of a novel gene cluster encoding staphylococcal exotoxin-like proteins: characterization of the prototypic gene and its protein product, SET1. Infect Immun 68, $4407-4415$. 